\title{
The Analysis on the Introduction of Islamic Financial Model in Ethnic Region in Gansu, China
}

\author{
Haiying $\mathrm{Ma}^{1} \&$ Yike Yao ${ }^{1}$ \\ ${ }^{1}$ School of Economics, Northwest University for Nationalities, Lanzhou, China \\ Correspondence: Haiying Ma, Associate Professor, School of Economics, Northwest University for Nationalities, \\ Lanzhou 730124, China. E-mail: lxmahaiying8888@163.com
}

Received: November 16, 2013

Accepted: December 4, $2013 \quad$ Online Published: January 10, 2014

doi:10.5430/ijfr.v5n1p114

URL: http://dx.doi.org/10.5430/ijfr.v5n1p114

This work was supported by the Fundamental Research Funds for the Central Universities of Northwest University for Nationalities (Grant No.31920130099).

\begin{abstract}
The United States sub-loan crisis has caused a serious worldwide financial crisis. However, during the time when lots of western financial institutions broke down, Islamic financial institutions just received tiny impacts. The unique investment philosophies of Islamic finance draws more and more people's attention. Linxia Hui Autonomous Prefecture, which is called "the eastern Mecca", has gained the humanistic connotations and environmental advantage of Islamic culture by nature. Thus, it will be easy to establish the relationship of cultural communication and financial cooperation. To set up an Islamic financial model which suits the economic characteristics of the ethnic region will solve the problem of bottleneck on financing effectively. It may also make a contribution to avoid financial crisis, increase the vitality of substantial economic, combine Islamism to modern financial system, as well as prompt the economical stable development.
\end{abstract}

Keywords: Islamic financial model, ethnic regions, investment philosophy, Linxia

\section{Introduction}

Since the 1990s, the main middle east of the petroleum exporting countries shows large amounts of capital surplus. Islamic financial business received widespread attention and started to be respected by the Arab world and western countries. One of the reasons is that the petroleum capital needs investment channels which suit Islam. The other reason is to fulfill the demand of the increasing Islamic clients. The service scope of Islamic financial institution, which regarding as a newly emerging power, has expanded from the Middle East, the Southeast Asia to Europe and United states, even all over the world gradually. During the sub-loan crisis, the western financial system had suffered a series of serious strikes, as well as the Asians. However, the Islamic financial system just received a tiny impact. It is mainly benefit from some principles like "Sharing profits and risks", "inadmissibility to conduct uncertain risky trades". The Islamic financial institution far away from Wall Street high risk financial derivative instruments and product and it's concept of stable operation is worth to use and be referenced.

\section{The Realistic Significance of Distinctive Islamic Financial Investment Concept}

Nowadays, the mysterious of Islamic world seems to spread from daily life to business world and financial sector, Islamic finance is the focal point of world attention obviously. But how to set up banking business without interest, as well as how to issue bond without the commitment of the interest in return is still mysterious for us. Islamic finance is trying to reverse our thinking and create a new opportunity of financing.

In 1970s, leaders of some Islamic countries, such as Libya, Iran and Pakistan, had suggested creating a kind of "Third-way" that is non-capitalist as well as non-socialist. Islamic world had emerged a international revolution, which is characterized the establishment of Islamic banking behavior during this time (Alkassim, F. A. 2005). Since 1980s, Islamic finance has developed in Southeast Asia Islamic countries. In 1990s, it entered western financial system successfully. Because of the huge potential of Islamic finance, some powerful multinational banks, such as the Citibank and the HSBC had devoted to this market. The international finance corporations, the World Bank, the Asian development bank, the Swiss food company nestle and the Germany Isaacson company - Anhalt state had 
issued Islamic bonds.

For the past thirty years, Islamic finance not only survived among the competition of the eastern conventional finance, but also shows a trend of stable and fast development. In 1980s, a report by the international monetary fund suggested that Islamic financial institution could solve financial crisis more easily so that it is more stable than western financial system. The implementation of this kind of system fully reflects the superiority of economic theory. As for the conventional financial system, during when the debt written value is constant, asset losses will cause the unbalance between the real value and the debt value of the assets. Moreover, it would shake the whole financial system (Hassan, M. K., \& Bashir, A. H. M.2003)

Islamic finance is the financial transaction which is fully comply with Islam, it is also called "Sharah compliant Finance". The opposite, which we are familiar with, is called conventional finance. Islamic finance is a series of theory on principles which are based on Islamic economic theory and they are adapting to the new form of financial theories and rules. The core concept of Islamic is interest free. But it is complementary to the other principles in Islam, such as sharing risks, the divine of the responsibilities in individual right and property right, etc. It also highlight that capital should always be related in practical production, the importance of fair distribution of wealth, as well as social ethics.

Comparing with the western financial institution which mainly stress cost and profit, Islamic financial institution includes more social public welfare. Islamic finance engage with the business which follow the Islam, avoid relating in speculation, liquor, cigarettes, weapon, pork production, gambling, and some activities which are involving in genetic engineering. Islamic finance forbids speculation and limits high risk investment. Islamic financial institution not only limits in banking sector, but also involves in the capital market and all kinds of financial intermediaries. Nowadays, there are over 300 Islamic banks in the world, spreads from over 70 countries. The total value reaches five hundred billion dollars and it is predicting to be doubled in 2010. Although the Islamic finance just has a tiny market share towards the whole banking world, but the growth rate is over $15 \%$ per year

\section{The Review of the Foundation and Development of Islamic Finance}

On the pattern which was built by Islamic Bank, Qureshi has made his point that bank should be set up by government and belong to the category of social services such as public health and education which is invested by bank and found by clients. It should not provide interest to savers or charge to lenders. In the "Islamic Economic" which was published in 1952, Ahmad had ever assumed that Islamic bank needs to be set up in the form of joint shock system. The bank offers not only current deposit but also accounts who participate in reserving fund, and then savers should give the interest to conventional bank interest. He suggested that the bank should change current deposit into commercial check. In 1955, Uzair had considered that the sharing on profit as well as loss of contract should be the basement of the interest free bank in the premise of not using deposit for investing. So the conception lacks of feasibility. In 1966, A12 Arabi designed a innovation for bank. It was based on the core of the contract for profit and loss sharing; both the bank and savers are the main body of investing and operating. It had become the prototype of the contract for profit and loss sharing for the modes of business in Islamic financial institutions.

The earliest systemic study of the Islamic financial investment was done by M.A.han. His research includes the phenomenon in Sudan, UAE, Kuwait, Bahrain, Jordan, Egypt and so on. He considered that Islamic bank has two ways of investment; one is that savers authorize the bank to invest in any projects; the other is that savers have right to choose which project should invest in. Islamic bank tends to trade, real estate and some efficiency short-time projects. Then Ipbal and Mirakhor did researches in Iran and Pakistan, described the process of financial system in Islamic style, financial tools and others problems. In 1982, Chapra thought Islamic bank should be based on the contract for profit and loss sharing, setting up funds for subsidizing deficits and insurance mechanisms of compensation in lost, financiers and entrepreneurs run their business in the premise of alliance. In 1985, Chapra said that Islamic bank should be concerned more about social welfare, not the profit maximization. He supposed that funding markets of interbank loan as conventional bank, placing reserve requirement in the center bank to deal with problems in shortage of funds. In the view of Mohsin, Islamic bank combined commerce into investment, with some services even not for bank, such as the trust business, the consulting of real estate agent. He also explained the feasibility of check free bank and servicing bank coexists in detail. Uzair held that the center bank should own the shares of Islamic bank, adjusting the ratio of distributing profits. Siddiqui also proposed that the center bank adjust the ratio of loan from Islamic bank according to the changed situation. Ensuring the center bank can get permanent profit is the foundation of the proposal to act as a requester of commercial bank.

In 2004, Xu Liping suggested that in the premise of the combination of Islamic financial institution and conventional financial institution and as the important supplement of conventional financial system, Islamic financial institution 
plays an important role in economic operation from Malaysia. Under the new situation, contractual cooperative relationship can help small and medium-sized enterprises to overcome the difficulties in financing. In 2005, Zhang, Xiaofeng held that the primary condition to bring in Islamic financial capital is to obey the Islamic law. China, which is a developing country and Muslim became potential motivations of Islamic finance development. In 2006, Yi Cheng analyzed the principle of Islamic financial institution as well as its profitable product detailed, which mainly emphasize difference in return and risk and the patterns of investing operation between the product of Islamic finance and conventional finance. In 2006, Li Wenrui explored the development and features of products for Islamic bank and some questions about cooperating with conventional banks in northwestern China. He suggested that comfortable environment should be created for Islamic bank to reach financial markets in the northwestern area, stepping up the pace of achievement of the northwestern Islamic bank, highlighting further study in Islamic bank in order to set up a financial system with Chinese characters. In 2009, Xu liping regarded that there is no legal barrier when foreign banks enter our country now. But the management of Islamic finance is limited for the production, which restrict the development of Islamic finance and Muslim's participation. Choosing a high Muslim population area to develop Islamic finance preferentially is a nice way to reduce the conflict in some extent.

\section{The Advantages of Gansu to Recommend Islamic Financial System}

In the situation of the financial crisis intensified, the conspicuous performance of Islamic finance attracts more attention from many countries. Britain set up England Islamic Bank and European Islamic Investment Bank in 2004. In January 2007, Britain pointed out the idea for London as the portal of Islamic finance and declared the new legislation of promoting the Islamic bond issuance. November 2007, the British Finance Service Authority (FSA) has produced documents, trying to make the Britain an advanced center of Islamic finance in areas. Other countries each take some action, as Paris and some cities of French opening fast channels of Muslim countries, Malaysia being developing the Islamic finance to the position of financial policy, Singapore trying to consolidate and develop finance center and the Hong Kong having applied to become the member of Islamic finance committee. In late 2007, it succeeded in introducing Islamic fund and now is amending the tax regulations to develop Islamic bonds. We hold that we shouldn't lose the valuable opportunities since everywhere attract Islamic investment, instead of taking full advantage of the western ethical region themselves, as well as leading the Islamic finance for local conditions.

There are more than 20,000,000 Muslim in China who mostly in Ningxia, Gansu, Yunnan, Qinghai, Xinjiang and other western provinces which have some researchers who are familiar with Islamic low and it's economic thought that benefits the development of the Islamic finance. Linxia Hui Autonomous Prefecture has a unique condition to contact with Islamic nations. The first is the advantage of it's Islamic culture and the population of Moslem; second, it has many national licensed products. Muslim food, handmade carpets, brick caring and some national supplies are popular. But Linxia is a poor area that is limited by the shortage of funds and low opening, so the development of project is restricted. However, the infrastructure accords with teaching of Islam which creates an opportunity for Islamic finance to reach those western areas as Linxia. Thus, with the permission of the law, looking for the maximum of cooperation, stepping up the pace to bring in foreign investment, filling in the blanks of funds of projects, creating comfortable environment of Islamic financial investment, building the bridge of Islamic finance investment, setting up an internationalized and diversified Islamic bank in some areas as Linxia to promoting leap-forward development of economic society in western ethnic region.

\section{The Consideration of the Recommendation of Islamic Financial System in Gansu}

As the unique Hui Autonomous prefecture, Linxia has a conspicuous humanistic connotation. Linxia has the Muslim population of $1,100,000$ which is distributed in all county, $56.2 \%$ of the total population. The other minorities also show their respect to Islamic culture fully. Islam has long history and profound influence in Linxia. Islam was first preaching during Tang dynasty. Trough the widely spread in Song, Yuan, Ming and Qing dynasty, Linxia has became a prosperous place of Islamic culture and then was called the eastern Mecca. Islam has influenced a lot among the daily lives and business events. In order to adapt the economic development in Gansu nationality region, at the premise of obey the Islam and the relative religious principles, PBC authorized to set up a financial institution which followed the way of Islamic bank. Hezhou Islamic financing company was found with the ethic characteristics financing group which active in the northwest ethic region. It is the only institution which replaces the legal interest rate with the deposit rate of return and the share rate of loan. With the adopting of the brief frequent and fast banking method, Hezhou Islamic financing company has made an amazing progress during twenty years. It has explored a new way and accumulates experiences for banking sector in ethic region. It also made an irreplaceable contribution in supporting local economic construction, small and mid-sized enterprise, especially in private-owned enterprises and self industrial business. We considered that Linxia could be the Pilot city which introduces Islamic financial 
system firstly. The way of Linxia should be issuing Islamic bonds to financing with the advantages of projects, then establishing Islamic bank or Islamic business window gradually. The details are as follows:

First, set up the inland fundamental system of the Islamic finance. A strong legislation and a legislature should be needed to handle the deviation and contradictions between Islamic financial institution and modern financial system, making use of the memorandum of understanding from government and international Islamic financial market to set standards of Islamic investment market. Moreover, set a stage of disclosure in Islamic finance to diffuse information freely and internationally, establish the policy and managerial system for Islamic finance to reach our country, which especially about the joint investment patent of risk sharing, the investment evaluation system of developing project and so on.

Second, train financial talents who can master Arabic, negotiate with Muslim nations to make long terms of cooperation in education and establish some relevant degrees with University for Nationalities, which set up a certification system of education center and Islamic finance; make flexible and preferential policy in local level; adjust relevant rules about judicature, taxes and accounting for establishing an accounting system and an accounting standard that match with Islamic teaching and manners of economic activities to make Linxia be the pilot of introducing Islamic finance in Gansu national region and led useful experience to western ethnic regions for Islamic finance further, thereby establish Islamic financial institution with Chinese characteristics.

Third, give a priority to develop Islamic bond in short time. Islamic bond is a virtually financial contract that contacts with asset performance of in-kind support in securitization. Considering Islamic bond is an important force to promote the development of Islamic finance rapidly, government and the relevant institution are main issues who make the sale increase rapidly. Linxia can make use of the management tools of Islamic funds to bring in the Islamic investment for local economic contraction which depends on the advantage of projects. Thus, the writer advises to introduce Islamic investment with the patterns of issuing Islamic bond overseas recently and the form of lease can commonly be a kind of issuing Islamic bond, which was guaranteed from government.

Fourth, set up Islamic bank in the mature period. According to the international convention, when Islamic investment is introduced and developed, the windows of Islam can be open by the existing institution or establish the Islamic financial institution separately. Considering now banks in our country lack of experience in managing Islamic financing, and there are some Islamic bank which are well-managed, powerful and having perfect inner control system trying to enter Chinese markets. Linxia can take account of setting up joint Chinese-foreign Islamic bank in mature period. With the thought of promoting the development of finance, another deep meaning in cooperation that changes the situation of local financial institution rapidly and promotes local establishment by introducing strategic investors.

Fifth, The varieties of Islamic financial institutions. There are many differences in business field between Islamic financial institution and traditional bank because Islamic bank can't charge interest. Here are some relevant modes of business. To saving business, Islamic bank provides the patterns of savings deposit that preserving capitals rather than profits (according to the situation of profits, the bank will think about how to share profits) and neither preserving capitals nor profits (sharing the investment profits or losses according to the stipulation ratio) on investment deposit and specific investment deposit. Aimed at "large" investors and institution investors, the difference from general banks was that specific investors contact with the projects of specific investment, the investors can invest their favored projects of bank directly. For the mortgage businesses, the patterns of Murabahah (sales of the capitals and profits) can be carried out. Islamic bank acts as purchasing agent for customers when the customers have agreed on house price with sellers, then the bank resells the houses in the way of capitals and profits. Customers can purchase a certain ratio (such as $25 \%$ ) and other funds can be deducted from lenders' wage monthly in loan. To consumer credit, for avoiding going against Islamic teaching, the way of rent-to-own can be used, as the bank purchases consumer durable goods to sublet to customers and sell to them at the end of lease. The mode of Mudarabah adapted to invest for financing of small and medium enterprises.

\section{Conclusion and Implications}

Throughout the development of Islamic financial market, it is easy to find out that the government plays an important role in inspiration and supporting. We have considered that Linxia could follow the pattern of Hong Kong, form a group by government to do economic and trade negotiation and take this chance to promote local banking service to cooperate with Islamic financial institution. Apart from that, because the difference of supervisor system of Islamic financial institution in revenue and law, it is necessary to do further study in Islamic financial theory and the cultivation of talents. Islamic business obeys the rule of "sharing profit and loss". As a religious safety financial way, it not only enriches the diversity of banking system, but also supports and complement to the traditional financial 
system. It will make big differences to avoid the financial risk, enhance the vitality of the real economic, combine Islam with modern financial institution and stabilize the economic development progress in ethnic region.

\section{References}

Alkassim, F. A. (2005). The profitability of Islamic and conventional banking in the GCC countries: a comparative study. Journal of Review of Islamic Economics, 13, 5-30.

Cao, Xiaochun. (2009). On Islamic Finance and its Introduction in Ningxia. Journal of Beifang Ethnic University, (14), 52-54.

Feng, Lulu. (2004, July). Contradiction of Religion and Development-Discussion on the Theory, Culture and Practical Conflict of Islam and Financial Globalization. Social Sciences in Ningxia, (4), 65-69.

Hassan, M. K., \& Bashir, A. H. M. (2003, December). Determinants of Islamic banking profitability. In the ERF Annual Conference, Vol. 16.

Imam P., \& Kangnik. (2010). Islamic banking: how has it spread? IMFN Working Paper, Sep, 2010.

$\mathrm{Ju}$, qiang. (2008). A new upsurge and development of world Islamic financial system. International financial research, 11 .

Ma, Yuxiu, \& Qi, Xueyi. (2009). On Islamic Finance Ideology Studies. Journal of Beifang Ethnic University, (4), 43-47.

Wang, Jiyi. (2005). an introduction of Islamic finance based on PLS model. International finance study, (9), 42-49.

Wu, Yonggui, (1989). The International Financial Movements in Postwar Period. World Religious Study, 2.

Xu, Liping. (2004). An analysis of Islamic financial system in Malaysia. Southeast Asia Research, 1.

Zhang, Xiaofeng. (2009). Research to Introduce Islamic Financial Operation Mode-An Example of Ningxia. Economic research, (11), 97-99. 